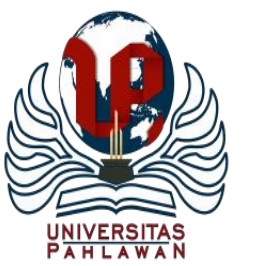

Jurnal Basicedu Volume 4 Nomor 3 Tahun 2020 Halm. 765-774

JURNAL BASICEDU

Research \& Learning in Elementary Education

https://jbasic.org/index.php/basicedu/index

\title{
Implementation Of Character Education In The Student Council
}

\author{
Meitriana Mezi ${ }^{1}$, Jagad Aditya Dewantara ${ }^{2}$ \\ Pancasila and Civic Education Study Program Universitas Tanjungpura, Indonesia ${ }^{1,2}$ \\ Mezimeitriana3984@gmail.com ${ }^{1,}$ jagad02@fkip.untan.ac.id ${ }^{2}$
}

\begin{abstract}
Abstrak
Penelitian ini bertujuan untuk mengetahui tentang "implementasi pendidikan karakter pada OSIS SMA Negeri 1 Pontinak". Metode yang digunakan adalah metode deskriftif dengan bentuk penelitian kualitatif. Sumber data penelitian ini adalah Pembina OSIS, peserta didik anggota OSIS dan siswa biasa yang bukan anggota OSIS. Teknik pengumpulan data yang digunakan adalah teknik observasi, teknik wawancara dan dokumentasi, sedangkan alat pengumpulan data yang digunakan adalah panduan observasi, wawancara dan alat dokumentasi. Informan dalam peneltian ini berjumlah 11 orang. Hasil penelitian menunjukan bahwa Pelaksanaan pendidikan karakter pada OSIS SMA Negeri 1 Pontianak ialah melalui kegiatan pembinaan kesiswaan yang menanamkan nilai-nilai karakter terhadap peserta didik anggota OSIS yang direalisasikan oleh OSIS melalui kegiatan-kegiatan yang telah diprogramkan. Nilai-nilai karakter tersebut diantaranya ialah nilai karakter religius, tanggung jawab, mandiri, toleransi, peduli sosial dan peduli lingkungan. Evaluasi pendidikan karakter pada OSIS SMA Negeri 1 Pontianak dilakukan oleh Pembina OSIS dengan mengamati secara langsung perilaku paserta didik secara terus menerus disetiap kegiatan perencanaan maupun pelaksaan serta tingkah laku peserta didik sehari-hari dilingkungan sekolah.

Kata kunci: PPKn, pendidikan parakter, nilai-nilai karakter
\end{abstract}

\begin{abstract}
This study aims to find out about "the implementation of character education in OSIS 1 Pontinak State High School". The method used is descriptive method with qualitative research. The data source of this research is the Student Council Supervisor, student council members and ordinary students who are not student council members. Data collection techniques used were observation techniques, interview techniques and documentation, while the data collection tools used were observation guides, interviews and documentation tools. There are 11 informants in this research. The results showed that the implementation of character education in OSIS Pontianak 1 Public High School was through student coaching activities that instill the character values of student council members who were realized by the student council through programmed activities. The requested character values are religious character values, responsibility, independence, responsibility, social care and environmental care. Evaluation of character education in OSIS Pontianak 1 High School is done by the OSIS Trustees by observing directly the behavior of students in a continuous manner in every planning and implementation activity and behavior of daily students in the school environment.
\end{abstract}

Keywords: PPKn, character education, character values

Copyright (c) 2020 Meitriana Mezi, Jagad Aditya Dewantara

Corresponding author :

Address : Jalan Prof. Dr. H. Hadari Nawawi, Pontianak 78124

Email : mezimeitriana3984@gmail.com

Phone : 085845918906

ISSN 2580-3735 (Media Cetak)

ISSN 2580-1147 (Media Online)

DOI: https://doi.org/10.31004/basicedu.v4i3.429 
DOI: https://doi.org/10.31004/basicedu.v4i3.429

\section{INTRODUCTION}

The problem of education in Indonesia is very complex, education in Indonesia faces many problems and problems that continue to this day (Perdana, 2018), namely experiencing a moral crisis towards the nation's next generation (Onde et al., 2020). Moral decline and character has been rampant in the world of education (Toni \& Mediatati, 2017), one of them is juvenile delinquency (Indratmoko, 2017). This can be seen from a variety of cases committed by students including brawls, truant, violations of the order as if, even to the act of violence, drug murder to be involved in prostitution cases online (Achmad \& Rizal, 2017).

We can also see various cases of moral and character entanglement among young people in West Kalimantan, where teenagers hang out late at night until they are given a reprimand by the police team (Tribunews, 2019), 19-year-old teenager determined to hang himself on the toilet allegedly because he had a romance problem (TribunMempawah, 2019), the death of a teenager due to beaten by 4 people who are also teenagers (TribunSingkawang, 2019), High school students give birth in the Puskesmas toilet (Shelavie, 2017).

Seeing a variety of cases that occur then the Indonesian nation is currently in need of character education to overcome the decline of the nation's cultural values (Soedjatmiko, 2015). Character education is an important aspect for the development of human resources, is an effort to help the development of children's souls, the process of forming the character of the nation's children who are expected to be the main foundation in improving the dignity of the Indonesian nation (Julistaty \& Madhakomala, 2018). Character education is a basic element of education especially for young people (Algera \& Sink, 2002) which is approved is capable of instilling new abilities to enhance new knowledge and skills that can be acquired by creative and critical humans. Character education empowers students to become responsible agents who question their choices affecting themselves and others, and to help students develop specific skills for making wise and ethical decisions (Kann, 2010). By placing the education strategy as the main capital to prevent the growth of the nation's destroyer viruses as stated above, this nation will be saved (Hartini, 2017).

Character education is a conscious effort made to shape students into positive personalities and morality according to graduation competency standards (Susiyanto, 2014). Character is the values of human behavior related to God Almighty, self, fellow human beings, environment, and nationality, which reside in thoughts, attitudes, feelings, words, and actions based on religious norms, law, manners, culture and customs (Fitri, 2012), So that it can be applied in everyday life. Values will be valuable if useful, true, moral, ethical and religious (Dewantara et al., 2020). So in the implementation of character education preinstill character values are expected to be applied by all education units in an integrated way in learning in class and school culture.

The development of secondary schools cannot be separated from the role of the IntraSchool Student Organization (OSIS) as one of the 
students' character education strategies (Hajar et al., 2019), Republic of Indonesia National Education Law Number 39 Year 2008 concerning Student Development, student organizations in schools that form the Intra-School Student Organization which is an official organization in schools which is one of the links to organizations that provide various functions (Achmad \& Rizal, 2017). Likewise, OSIS as an organization that has several functions and objectives in achieving its will. The student council is managed and managed by the students chosen to be student council.

SMA Negeri 1 Pontianak, or better known as the acronym SMANSA is one of the state senior high schools in the city of Pontianak, West Kalimantan, which was founded on September 14, 1953 with the number of students now 1212 people. SMA Negeri 1 Pontianak is known as one of the superior and favorite high schools in the province of West Kalimantan with an A accreditation ranking, seen from the achievements that have been achieved by these schools from local and national levels. This is certainly inseparable from the role of elements in the school, one of which is the role of the student council which is an official organization that is in school as a container, motivator / motivator and student coaching which certainly cannot be separated from the implementation of character education that will produce students quality and be an example and role model for other students outside the student council. Based on the results of pre-research conducted through observations of OSIS and interviews with supervisors of OSIS, the researchers concluded that the OSIS Pontianak 1 SMA had implemented character education.

This is evidenced by the participation of OSIS in the activities "spiritual development" which was carried out in Bogor as a delegation of West Kalimantan. Therefore, the researcher wants to know and describe the process of implementing character education from the implementation, the character values given to student members of the student council and the evaluation of character education at the student council.

Several similar studies have been carried out including, inculcation of citizenship attitudes through activities where Intra School Student Organizations (Achmad \& Rizal, 2017), character development strategy through the activeness of organizing Intra School Students (Hajar et al., 2019), the role of intra-school student organizations in forming student characters (Toni \& Mediatati, 2017), the formation of school attitudes through the application of character education (Susiyanto, 2014), and the nature of Pancasila in shaping national character through intra-school student organizations (Damanik, 2014).

This study would like to add to the study of the implementation of character education in OSIS with a focus on research ranging from the implementation of character education, character values given to the evaluation of character education at OSIS. This study aims to determine and describe that the implementation of character education is very important to give to students in order to produce quality students that are useful for themselves, families, communities and countries. 
Therefore, researchers conducted research under the title "Implementation of Character Education in OSIS Pontianak 1 High School".

\section{METHOD}

This research uses a qualitative approach. Qualitative research is a study aimed at describing and analyzing phenomena, events, social activities, attitudes, beliefs, perceptions, thoughts of individuals individually or in groups that take place without any (natural) setting (Moleong, 2017). Researchers use descriptive research types, namely research that seeks to describe, interpret and describe or explain objects, events and events that are taking place at the time of the study in accordance with what actually happened (sukardi, 2007). Researchers use descriptive type because it aims to provide an overview, explore, disclose and present data naturally with facts and according to the original circumstances about the implementation of character education that is focused on how the implementation of character education in the OSIS, the values given to the student council members and the evaluation of character education itself at the student council. The location of the study was conducted at SMA Negeri 1 Pontianak.

In this study, researchers as instruments as well as data collectors. The observer's role is to take part in the phenomenon or habit under study. Then, researchers make in-depth observations in data collection efforts. In this study, primary data obtained from interviews with informants consisting of being informants were OSIS coaches, student council students (chair, deputy, secretary,
EOO coordinator, designer, public relations, discipline, divinity, and non-student council students after the data was collected. Next will be analyzed with the steps in the activity of data analysis, namely data reduction, data display, and conclusion drawing / verification.

\section{RESULTS AND DISCUSSION}

\section{Implementation of Character Education at OSIS Pontianak 1 High School}

Based on the results of research and data it can be said that the implementation of character education in OSIS Pontianak 1 High School is through student coaching activities that instill the character values of student council members realized by the student council through activities that have been programmed by student council members assisted by student council members by the Student Counselor and the Class Representative Meeting (MPK) has had a positive impact on the school community especially on the student council members and can be used as an example/example for other students.

The process of implementing character education contains three components, namely moral knowing, moral feeling, and moral action (Lickona, 1991). The cultivation of moral knowing aspects is more likely to be instilled through learning in the classroom, while moral feeling and moral action are instilled both inside the classroom and outside the classroom where moral action must be carried out continuously through daily habits (Maunah, 2015).

The implementation of character education in OSIS SMS Negeri 1 Pontianak through several 
types of fostering activities in celebrating religious holidays such as Eid al-Adha and Christmas, celebrating national holidays such as batik, Kartini, youth vows, independence, LDKS activities (Basic Leadership Training), holding social services, classmetting, holding health seminars and environmental care which starts from the planning, implementation to evaluation.

Student coaching activities are part of the implementation phase of character education in schools (Hajar et al., 2019). Coaching means the business or activity provides guidance, direction, improvement to the first way of thinking or how to judge and draw conclusions about something based on a particular point of view. second, mental attitude is the conception of behavior that arises from one's soul as a reaction on the basis of the situation that affects it. Third, behavior that is action or activity. Fourth, interest in talent and skills (Wahjosumidjo, 2010). Through this student coaching activity slowly the character of students will be formed, perceived to be better as it should be.

Based on the regulation of the Minister of National Education of the Republic of Indonesia Number 39 Year 2008, student development is an activity to develop the potential of students with the functions and objectives of national education, namely students who have faith and are devoted to God Almighty, noble, healthy, knowledgeable, capable, creative, and independent, and become a citizen who is dermokratis and responsible, it is necessary to foster students in a systematic and sustainable manner.
The purpose of student coaching is first, to develop students' potentials in an optimal and integrated way that includes interests, talents and creativity. Secondly, it strengthens the personality of students to realize school resilience as an educational environment so as to avoid negative efforts and influences and conflict with educational goals. Third, actualize students' potential in achievement according to their talents and interests. Fourth, prepare students to become noble, democratic citizens who respect human rights in order to realize civil society.

According to Ratna Megawangi as quoted by Syarbini (2012), character education is an effort to educate children to be able to make wise decisions and practice them in their daily lives, so that they can make a positive contribution to their environment. In this country character is an indispensable thing, because if the character is lost, it will cause the loss of the next generation. Character does not come by itself, but must be built and formed to create a dignified country (Sulistyarini et al., 2020).

In order to strengthen the implementation of character education, the government has actually identified 18 values originating from the religion, culture and philosophy of the nation, namely: (1) religious, (2) honest, (3) tolerance, (4) discipline, (5) hard work , (6) creative, (7) independent, (8) democratic, (9) curiosity, (10) national spirit, (11) patriotism, (12) respect for achievement, (13) friendly / communicative, ( 14) peace-loving, (15) fond of reading, (16) care about the environment, (17) care about social and (18) responsibility. 
These character values can be the basis for understanding the character of the nation, which is now starting to fade because of the lifestyle of hedonism and modernism (Ichsan \& Samsudin, 2019).

\section{Character Values Given to Student Participants in the Student Council of SMA Negeri 1 Pontianak}

The essence of character education is not only teaching, telling about what is good and what is not good, but character education is also the process of instilling (internalizing) positive values

to students through various appropriate methods, value as something that is valuable, good, noble, desirable and considered important by society in turn needs to be introduced to children (Yanti et al., 2016).

The character values given to students of student council members can be known from the activities of student coaching starting from the planning stage of an activity, the implementation and evaluation of each activity carried out. The character values consist of religious, responsibility, independence, tolerance, care for the environment and care for the social.

First, the implementation of religious values by greeting, praying, celebrating religious holidays (Dewantara et al., 2020), mentioned that one of the religious values can be done by holding religious activities. Religious values can be applied or implemented by greeting, praying before and after learning, carrying out religious worship and celebrating religious holidays (Fitri, 2012). Religious means believing in God Almighty and always obeying his teachings with attitudes and behaviors that reflect beliefs and trust in God Almighty (Zuriah, 2015), attitudes and behaviors that are obedient in carrying out religious teachings that are adhered to, tolerant of the implementation of other religions and living in harmony despite different religions (Yaumi, 2016). Religious is one of the character values that is used as an obedient attitude and behavior in the religion or belief adopted, tolerant of people of different religions, living and in harmony with other religions. The character of religious values is highly needed by students in facing the changing times and moral degradation as it is today (Sulistyarini et al., 2020).

Second, the implementation of the value of responsibility by always being trustful in carrying out the tasks that have been given. Being responsible means doing every task given, being responsible for every deed, carrying out pickets according to the schedule, doing group assignments together (Fitri, 2012). Having a sense of responsibility means the attitude and behavior to carry out their duties and obligations towards themselves, society, the environment, the State and God Almighty (Zuriah, 2015)

Third, the implementation of independent character values by not always depending on others in completing the tasks that have been given. Mandiri. An independent person is a person who is self-efficient, able to think and function independently, does not reject risks and can solve problems and can be useful for those closest to him (Mustari, 2014). 
Fourth, the implementation of the tolerance value by getting students to get along with anyone without discriminating between religion, ethnicity, race, economy, treating friends fairly. Tolerance is an attitude and action that respects differences in religion, ethnicity, opinions, attitudes, and actions of others who differ from our opinions (Yaumi, 2016). We have a tolerance value if we treat others without discrimination in any aspect (Fitri, 2012).

Fifth, the implementation of social care by conducting devotional programs social, collecting donations for their friends who get a disaster. Social care is the attitude and act of providing assistance to people in need (Yaumi, 2016). Social care can be carried out by providing assistance to others, carrying out social service activities, conducting visits to remote areas, providing assistance to disadvantaged communities, providing charity boxes and donations (Fitri, 2012).

Sixth, the implementation of caring for the environment by always paying attention to the environment of the school and its surroundings, holding activities related to environmental awareness actions such as holding seminars commemorating national waste days followed by cleaning up the school and surrounding environment and processing used items for use and use. This is in line with previous research in which environmental attitudes can be done by recycling waste, environmental awareness education (Prasetiyo et al., 2019). Caring for the environment is an attitude and action that always seeks to prevent damage to nature, developing efforts to repair natural damage that has already occurred
(Yaumi, 2016). Attitudes and other actions to care for the environment are to maintain the classroom and school environment, care for plants, available waste disposal sites, always care about environmental hygiene (Fitri, 2012). By protecting the environment, we have shown an attitude of nationalism, where we strive, work hard to protect our homeland (Dewantara \& Budimasyah, 2018).

\section{Evaluation of character education at OSIS Pontianak 1 High School}

Every society in any part of the world really needs the younger generation to be prepared to become good citizens and be able to participate in the lives of their people and countries, this desire is more accurately described as a growing concern especially in democratic societies (Dewantara et al., 2019). Character education aims to produce students who are able to compete, have ethics, have morality, are polite, and are able to interact with the community. Soft skill education rests on mental development so that students can adjust to the realities of life.

Based on the observations of the student council and the results of interviews with the student council coach for the evaluation of character education at the student council itself, it was not only seen from the success of an activity they carried out but also seen from the habits of the student council members in the school both outside and in the classroom. observing how their planning process towards the activities carried out and at the time of the implementation of the activities themselves. The coach not only observes in one activity or within a period of one or two 
days, but also observes or observes in every planning and implementation activity as well as the daily behavior of students in the school environment. This is consistent with the results of previous studies (Maunah, 2015) that evaluation of character education can be carried out by observation by making direct observations including the attitudes of students with teachers, school discipline, education personnel and fellow students, their discipline in waiting for school discipline, following extracurricular activities.

\section{CONCLUSION}

Character education is the main step to shape and build the mindset and behavior of students to become positive individuals so that it can be useful for the nation and state. The implementation of character education at OSIS Pontianak 1 Public High School is through student coaching activities that instill the character values of student council members who are realized by the student council through activities that have been programmed. These character values are religious character values, responsibility, independence, tolerance, social care and environmental care. Evaluation of character education in OSIS Pontianak 1 High School is done by the OSIS Trustees by observing directly the behavior of students in a continuous manner in every planning and implementation activity and behavior of daily students in the school environment.

\section{BIBLIOGRAPHY}

Achmad, \& Rizal, S. (2017). PENANAMAN SIKAP KEWARGANEGARAAN MELALUI KEGIATAN ORGANISASI SISWA INTRA SEKOLAH ( OSIS ) DI SMK NEGERI 1 CERME GRESIK Suharningsih. Kajian Moral Dan Kewarganegaraan, 01, 66-83.

Algera, H. F., \& Sink, C. A. (2002). Another Look at Character Education in Christian Schools. 1(2), 161-181.

Damanik, F. H. S. (2014). Jurnal Pendidikan IlmuIlmu Sosial Hakikat Pancasila dalam Membentuk Karakter Kebangsaan melalui Organisasi Siswa Intra Sekolah. 6(2), 49-60.

Dewantara, J. A., \& Budimasyah, D. (2018). Mutual Cooperation Based Go Green: New Concept of Defense Country. April. https://doi.org/10.2991/acec-18.2018.10

Dewantara, J. A., Efriani, Sulistyarini, \& Prasetiyo, W. H. (2020). Optimization of Character Education Through Community Participation Around The School Environment ( Case Study in Lab School Junior High School Bandung ). Jurnal Etika Demokrasi, 5(1), 53-66.

Dewantara, J. A., Suhendar, I. F., Rosyid, R., \& Atmaja, T. S. (2019). Pancasila as Ideology and Characteristics Civic Education in Indonesia. International Journal for Educational and Vocational Studies, 1(5), 400-405.

https://doi.org/10.29103/ijevs.v1i5.1617

Fitri, A. Z. (2012). pendidikan karakter berbasis nilai \& etika di sekolah. Jakarta: AR- RUZZ MEDIA.

Hajar, S., Tinus, A., \& Budiono. (2019). PEMBINAAN KESISWAAN UNTUK PENUMBUHAN. Civic Hukum, 4(1), 56-66.

Hartini, S. (2017). Sri Hartini, Pendidikan Karakter Disiplin. Basic Of Education, 02(01), 38-59.

Ichsan, A. S., \& Samsudin. (2019). PENANAMAN PENDIDIKAN KARAKTER ANAK DALAM STUKTUR SOSIAL KELUARGA DESA DI YOGYAKARTA. Jurnal Basicedu, 3(2), 524-532. 
DOI: https://doi.org/10.31004/basicedu.v4i3.429

Indratmoko.

(2017).

PENGARUH

GLOBALISASI

KENAKALAN REMAJA DI DESA SIDOMUKTI KECAMATAN MAYANG KABUPATEN JEMBER J. Agung Indratmoko. Citizenship Jurnal Pancasila Dan Kewarganegaran, 5740.

Julistaty, M., \& Madhakomala, R. (2018). Manajemen Pendidikan Dalam Membentuk Karakter Siswa SMP Tunas Bangsa Sunter. Akuntabilitas Pendidikanendidikan, 6(2), 241-251.

Kann, M. E. (2010). Discipline, Character, and Education. Teaching Education, 6(1), 71-75. https://doi.org/10.1080/1047621940060109

Maunah, B. (2015). The implementation of character education in the formation of students' holistic personality. Pendidikan Karakter, 5(1), 90-101.

Mustari, M. (2014). Nilai Karakter Refleksi Untuk Pendidikan. Jakarta: RajaGrafindo Persada.

Onde, M. L. ode, Aswat, H., B, F., \& Sari, E. R. (2020). Integrasi Penguatan Pendidikan Karakter (Ppk) Era 4.0 Pada Pembelajaran Berbasis Tematik Integratif Di Sekolah Dasar. Jurnal Basicedu, 4(2), 268-279. https://doi.org/10.31004/basicedu.v4i2.321

Perdana, N. S. (2018). STRENGTHENING CHARACTER EDUCATION IN SCHOOLS AS PREVEN- TION EFFORTS FOR JUVENILE DELINQUENCY PENGUATAN PENDIDIKAN KARAKTER DI SEKOLAH A - PENDAHULUAN Dunia pendidikan saat ini sedang berduka, hal ini terjadi karena maraknya kasus kenakalan remaja. Kasu. 17(1), 32-54.

Prasetiyo, W. H., Kamarudin, K. R., \& Dewantara, J. A. (2019). Surabaya green and clean: Protecting urban environment through civic engagement community. Journal of Human Behavior in the Social Environment, O(0), 118.

https://doi.org/10.1080/10911359.2019.1642 821

Shelavie, T. (2017). Heboh Siswa SMA Melahirkan di Toilet Puskesmas, 4 Fakta Mengejutkan Ini Terungkap. https://www.tribunnews.com/nasional/2017/1 0/19/heboh-siswa-sma-melahirkan-di-toilet- puskesmas-4-fakta-mengejutkan-initerungkap.

Soedjatmiko. (2015). Journal of Physical Education, Health and Sport. Journal of Physical Education, Health and Sport, 2(2), 57-64.

Sulistyarini, Rosyid, R., Dewantara, J. A., \& Purwaningsih, E. (2020). Pancasila Character Education in Teaching Materials to Develop College Students' Civic Disposition. 418(Acec 2019), 325-330. https://doi.org/10.2991/assehr.k.200320.063

Susiyanto, M. W. (2014). ANALISIS IMPLEMENTASI PENDIDIKAN KARAKTER DISEKOLAH DALAM. 2(1), 62-69.

Toni, I. A. (2019). PERANAN ORGANISASI SISWA INTRA SEKOLAH (OSIS) DALAM MEMEBENTUK KARAKTER SISWA DI SMK NEGERI 2 SALATIGA. Satya Widya, 35(1), 54-61. https://doi.org/10.24246/j.sw.2019.v35.i1.p5 4-61

Tribunews. (2019). Polisi Suruh Pulang Remaja yang Nongkrong Hingga Larut Malam. https://pontianak.tribunnews.com/2019/10/15 /polisi-suruh-pulang-remaja-yangnongkrong-hingga-larut-malam

TribunMempawah. (2019, September). Diduga Punya Masalah Asmara, Remaja 19 Tahun Nekat Gantung Diri di Toilet. Tribunpontianak.

https://pontianak.tribunnews.com/2019/09/16 /breaking-news-diduga-punya-masalahasmara-remaja-19-tahun-nekat-gantung-diridi-toilet

TribunSingkawang. (2019). Empat Bocah di Singkawang Diduga Lakukan Pengeroyokan hingga John Felix Tewas. https://pontianak.tribunnews.com/2019/05/15 /breakingnews-empat-bocah-di-singkawangdiduga-lakukan-pengeroyokan-hingga-tewas

Yanti, N., Adawiah, R., \& Harpani, M. (2016). 963 PELAKSANAAN KEGIATAN EKSTRAKURIKULER DALAM RANGKA PENGEMBANGAN NILAI-NILAI KARAKTER SISWA UNTUK MENJADI WARGA NEGARA YANG BAIK DI SMA KORPRI BANJARMASIN. Pendidikan 
774 Implementation Of Character Education In The Student Council-Meitriana Mezi, Jagad Aditya Dewantara

DOI: https://doi.org/10.31004/basicedu.v4i3.429

Kewarganegaraan: Volume 6, Nomor 11, Mei 2016, 6(11), 963-970.

Yaumi, M. (2016). Pendidikan Karakter: landasan, Pilar \& Implementasi (2nd ed.). PRENADAMEDIA GROUP.

Zuriah, N. (2015). Pendidikan Moral \& Budi Pekerti Dalam Perspektif Perubahan (4th ed.). Jakarta: PT. Bumi Aksara. 